\title{
Antibiotic use during pregnancy: how bad is it?
}

Amir A. Kuperman ${ }^{1,2}$ and Omry Koren ${ }^{2 *}$

\begin{abstract}
Background: Our microbial companions (the "microbiota") are extremely important for the preservation of human health. Although changes in bacterial communities (dysbiosis) are commonly associated with disease, such changes have also been described in healthy pregnancies, where the microbiome plays an essential role in maternal and child health outcomes, including normal immune and metabolic function in later life. Nevertheless, this new understanding of the importance of the microbiome has not yet influenced contemporary clinical practice regarding antibiotic use during pregnancy.

Discussion: Antibiotic treatment during pregnancy is widespread in Western countries, and accounts for $80 \%$ of prescribed medications in pregnancy. However, antibiotic treatment, while at times lifesaving, can also have detrimental consequences. A single course of antibiotics perturbs bacterial communities, with evidence that the microbial ecosystem does not return completely to baseline following treatment. Antibiotics in pregnancy should be used only when indicated, choosing those with the narrowest range possible.

Summary: Bacteria are essential for normal human development and, while antibiotic treatment during pregnancy has an important role in controlling and preventing infections, it may have undesired effects regarding the maternal and fetoplacental microbiomes. We expect that microbiota manipulation in pregnancy, through the use of probiotics and fecal microbiota transplantation, will be the subject of increasing clinical interest.
\end{abstract}

Keywords: Microbiome, Gut, Fetus, Placenta, Amniotic fluid, Pregnancy, Antibiotics, Immune system

\section{Background}

The human body is home to a variety of microorganisms, termed the microbiota, consisting of up to 100 trillion bacterial cells, most of which reside in the gut. Large sequencing efforts, such as the Human Microbiome Project, have characterized the microbiota of the major sites (gut, mouth, skin, airways, and vagina) of the human body in healthy individuals and demonstrated that different body sites harbor diverse populations of microbes [1]. Our microbial companions are extremely important for the preservation of human health, and a growing number of studies describe how changes in these bacterial communities are linked to disease states such as obesity [2], diabetes [3], atherosclerosis [4], and autoimmune disorders [5], among others. These shifts in community structure are termed dysbiosis. Although dysbiosis is commonly

\footnotetext{
* Correspondence: korenomry@gmail.com

${ }^{2}$ Faculty of Medicine in the Galilee, Bar-llan University, Henrietta Szold St. 8,

POB 1589 Safed, Israel

Full list of author information is available at the end of the article
}

associated with disease, it has also been described in healthy pregnancies in which there is a bidirectional relationship between pregnancy and the microbiome, whereby pregnancy affects the composition of the microbiome and the microbiome plays a role in maternal and child health outcomes [4]. These shifts in microbial composition occur in several sites in the body of the pregnant woman.

\section{Maternal gut and vaginal microbiome changes during normal pregnancy and pregnancy complications}

Pregnancy is characterized by profound hormonal, immunological, and metabolic changes aimed at supporting the growth of the fetoplacental unit [6]. Interestingly, a healthy pregnancy also induces dramatic changes in the maternal gut microbiota over the course of gestation, with a great expansion of diversity between individuals, an overall increase in Proteobacteria and Actinobacteria, and reduced diversity within each microbiome. Similarly, the vaginal microbiome in pregnancy is different from that 
of non-pregnant women, with lesser diversity and richness, and with a dominance of Lactobacillus species, Clostridiales, Bacteroidales, and Actinomycetales [7]. When transferred to germ-free mice, third trimester microbiota induced greater adiposity and low-grade inflammation compared to first trimester microbiota [4], and it was recently suggested that alteration of the gut microbiota during pregnancy may also induce complications of pregnancy such as excessive maternal weight gain [8].

Maternal pregnancy complications significantly influence the bacterial composition and diversity of the stool microbiota of premature infants, with these changes persisting during the first year after birth [9]. Antibiotic usage during pregnancy undoubtedly affects the bacterial environment of the mother and of the fetus.

\section{Bacteria of the fetoplacental unit - more fact than fiction?}

We are rapidly progressing towards understanding the role of bacteria in novel target organs traditionally considered "sterile", including the central nervous system [10], blood [11], the lower airways [12], the sub-epidermis [13], and the fetoplacental unit [14]. 'The fetus lies in a sterile environment' declared the French pediatrician Henry Tissier of the Pasteur Institute in 1900 [15]; since then, the placenta was traditionally believed to form a sterile barrier between the colonized maternal urogenital tract and the fetus. However, recent studies have challenged this assumption. The first demonstration of bacteria in the placenta in the modern scientific literature was published in 1982 by Kovalovszki et al. [16]. Subsequent publications have described the placental microbiome, using culture-dependent and -independent methods, and suggested its relative similarity to the oral microbiome, with bacteria such as Prevotella tannerae and Neisseria being present in the placenta [14] (Fig. 1). Specific components of the placental microbiome have been linked to particular pregnancy complications (Table 1, Fig. 2). Several mechanisms of amniotic fluid colonization have been proposed, including the translocation of vaginal bacteria [17] via the bloodstream or from

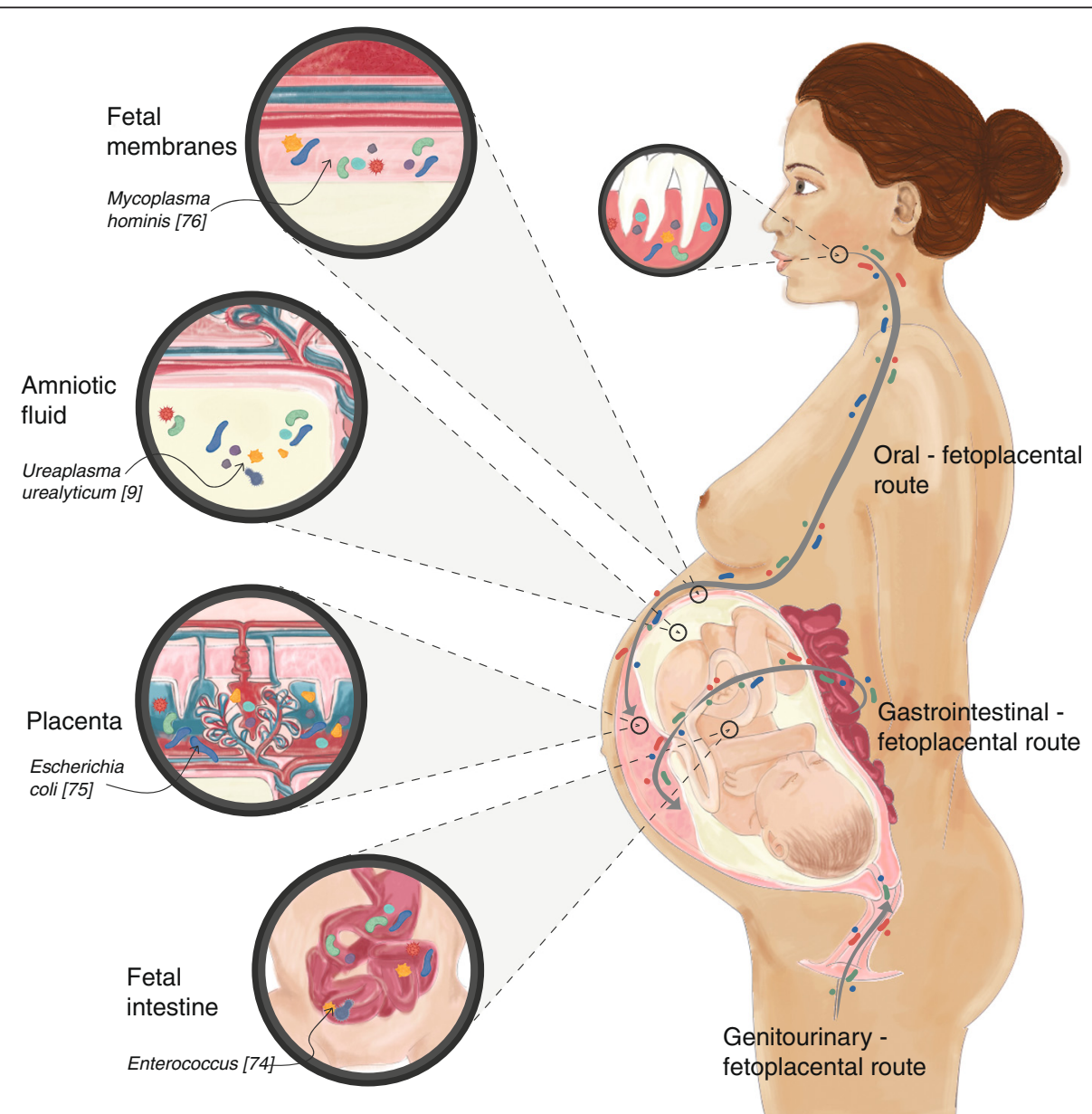

Fig. 1 The fetoplacental microbiome of healthy pregnancy and its origins. Bacteria and their genes have been isolated from human placentas, amniotic fluid, fetal membranes, and fetal gastrointestinal tract in healthy, normal pregnancies. These bacteria have three main routes of entry: the oro-fetoplacental route, the gastrointestinal-fetoplacental route, and the genitourinary-fetoplacental route. Examples of specific bacteria are indicated 
Table 1 Summary of studies providing evidence for bacteria in the human fetoplacental unit in both complicated and uncomplicated pregnancies ( $\boldsymbol{V}$ marks published evidence)

\begin{tabular}{|c|c|c|c|c|c|}
\hline Pregnancy state & Method & Placenta & Amniotic fluid & Fetal membranes & Reference \\
\hline \multirow[t]{3}{*}{ Normal pregnancy } & Microscopy & $\checkmark$ & $\checkmark$ & $\checkmark$ & {$[26,37-40]$} \\
\hline & Bacterial cultures & $\checkmark$ & $\checkmark$ & $\checkmark$ & {$[16,37,39,41-50]$} \\
\hline & Culture independent methods & $\checkmark$ & $\checkmark$ & $\checkmark$ & {$[14,26,37,38,41,43,45,50-62]$} \\
\hline \multirow{3}{*}{$\begin{array}{l}\text { Premature rupture of membranes } \\
\text { and preterm labor }\end{array}$} & Microscopy & $\checkmark$ & & $\checkmark$ & {$[41,61]$} \\
\hline & Bacterial cultures & $\checkmark$ & $\checkmark$ & & {$[16,20,39,44,50,52,57,63-69]$} \\
\hline & Culture independent methods & $\checkmark$ & $\checkmark$ & $\checkmark$ & $\begin{array}{l}{[14,16,19,20,39,42,46,50,} \\
52,53,61,70]\end{array}$ \\
\hline \multirow[t]{2}{*}{ Intrauterine growth restriction } & Bacterial cultures & & $\checkmark$ & & [71] \\
\hline & Culture independent methods & & $\checkmark$ & & {$[45,72]$} \\
\hline \multirow[t]{2}{*}{ Pre-eclampsia } & Bacterial cultures & $\checkmark$ & $\checkmark$ & & {$[46,72,73]$} \\
\hline & Culture independent methods & $\checkmark$ & $\checkmark$ & & {$[49,51,58,62,72,73]$} \\
\hline
\end{tabular}

the oral cavity [18]. Other possible routes include hematogenous spread or bacterial migration from the lower gastrointestinal tract to the lower genitourinary tract (Fig. 1).

The fetal membranes consist of the amniotic membrane, which contains the amniotic fluid, and the chorion, which is in proximity with the decidua parietalis. It has been shown that certain bacteria may be present in fetal membranes without leading to an inflammatory response [16]; Galask et al. [19] demonstrated that bacteria can traverse intact fetal membranes. Other bacteria resident in the fetal membranes are thought to play a role in amniotic inflammation, and thus in the initiation of labor [20].

Some of the studies described above demonstrated very low levels of bacterial DNA in the fetoplacental components. As detection methods become more sensitive, even more rigorous precautions must be taken against contamination when screening for bacterial colonization [21]. Nevertheless, despite the possibility of sample contamination, the physiological and beneficial presence of bacteria in the placenta is gaining widespread acceptance.

\section{Antibiotic use in pregnancy - an opinion}

Perhaps the most clinically relevant aspect of the pregnancy microbiome is antibiotic treatment during pregnancy. Antibiotics account for $80 \%$ of all prescribed medication in pregnancy [22], yet surprisingly, few published human studies have carefully evaluated the direct effects of antibiotics during pregnancy on either the maternal or fetal microbiome, or evaluated long-term sequelae of such antibiotic use. Thus, there may be a reason for caution in prescribing antibiotics during pregnancy.

In pregnant NOD mice, antibiotic treatment caused alteration of gut microbiota and immunological changes in the intestine of the offspring [23]. In pregnant women, it was demonstrated that antibiotic administration during pregnancy leads to alterations in the vaginal microbiome prior to birth, with long-term effects on the early microbial colonization of the newborn [24] and an association with childhood obesity [25].

There are several components to this issue. Antibiotic treatment of infectious diseases is one of the greatest advances of modern medicine. Accordingly, antibiotics are widely prescribed during pregnancy as the most important modality for treating and preventing infections. It is estimated that one in five pregnant women in Europe is prescribed at least one antibiotic during pregnancy; in the United States, the rate is double [26]. Nevertheless, prescription of antibiotics should be carefully considered on an individual basis, weighing its benefits versus drawbacks for both the fetus and the mother. It has been shown that administration of certain antibiotics is linked to a significantly higher rate of neonatal necrotizing enterocolitis, although antibiotic treatment is also associated with a reduced rate of lung complications and major cerebral abnormalities, relative to non-antibiotic treated controls [27]. A more recent study published in 2008 demonstrated that the prescription of antibiotics for women in spontaneous preterm labor with intact membranes was associated with an increased risk of cerebral palsy and functional impairment among their children at 7 years of age [28].

As discussed above, the healthy microbiome is important for maintaining a normal pregnancy and, therefore, it has been suggested that we may be using too many antibiotics during pregnancy [29]. A large systematic review concluded that antibiotics during the second and third trimester do not reduce adverse pregnancy outcomes and morbidity [30]. In addition, even a short course of antibiotics perturbs bacterial communities in human hosts [30]. In one study, it was shown that, within 30 days following cessation of antibiotic treatment, fecal microbiota reached an average similarity of $88 \%$ to baseline, with the level rising to $89 \%$ within 60 days [31]; 

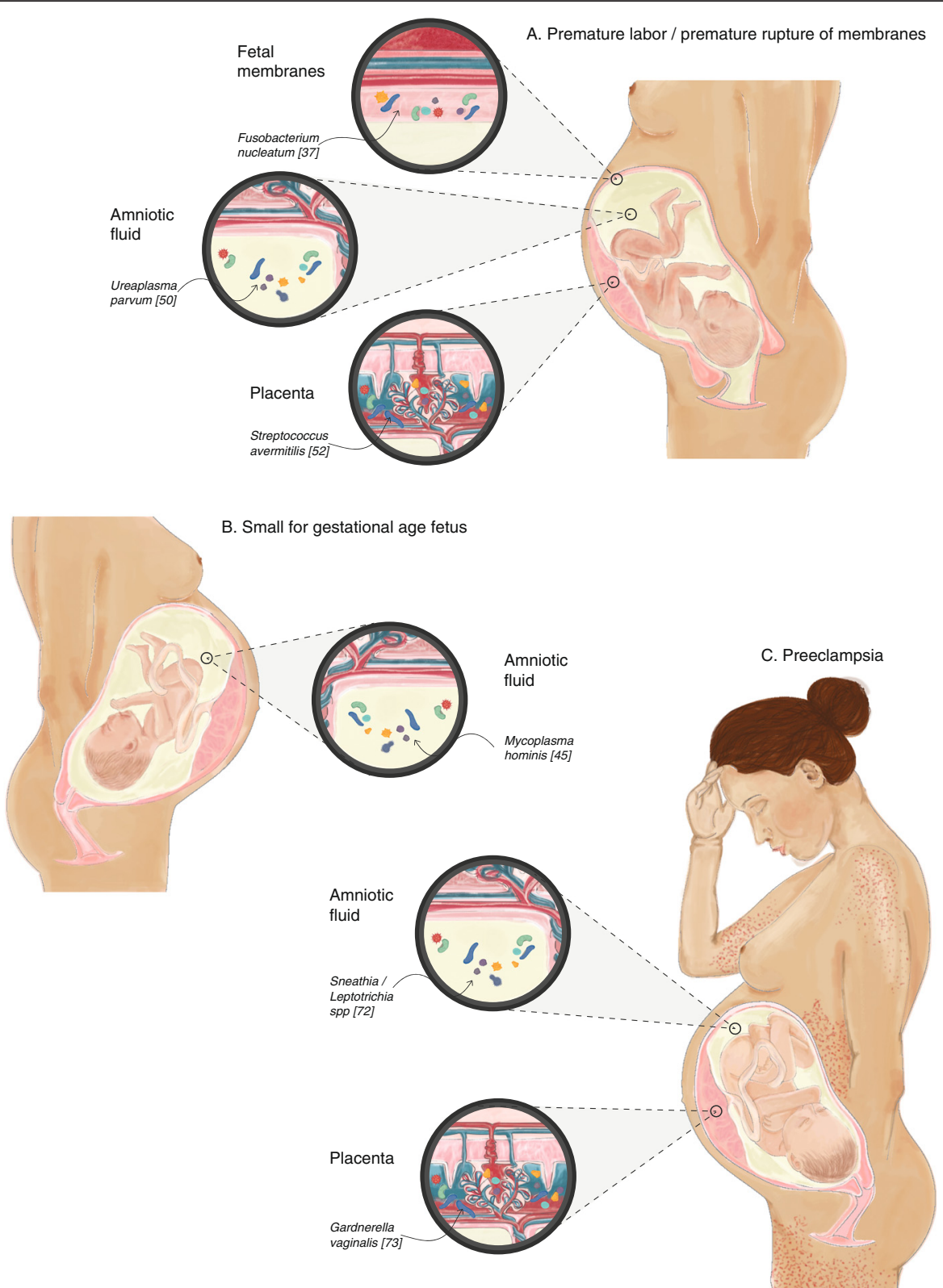

Fig. 2 The fetoplacental microbiome in various pregnancy complications involving the placenta. Examples of specific disease-associated species are shown. a Bacteria are found in the placenta (Streptococcus avermitilis), fetal membranes (Fusobacterium nucleatum), and amniotic fluid (Ureaplasma parvum) in cases of premature labor and premature rupture of membranes. b Bacteria are present in amniotic fluid (Mycoplasma hominis) in small-for-gestational-age (intrauterine growth restriction) fetuses. c Bacteria are present in the placenta (Gardnerella vaginalis) and amniotic fluid (Sneathia/Leptotrichia spp) in cases of preeclampsia. A pregnant woman is illustrated, exhibiting headache, edema, and petechia

however, the microbiota did not completely return to baseline over the timescale studied. Thus, antibiotics cause an immediate perturbation of the ecosystem, followed by incomplete recovery of the gut microbiome. The response to a given antibiotic is individualized, and may be influenced by prior exposure to the same drug. Accordingly, even a short course of antibiotics may sometimes have a long lasting residual effect on the microbiome, with possible metabolic or immune consequences.
The use of antibiotics during pregnancy has also been associated with increased risk of asthma in early childhood [32-34], increased risk of childhood epilepsy, and increased risk of childhood obesity [25]. Of course, the argument could be made that the primary maternal infection was the cause for the increased risk of these conditions, rather than the treatment itself. Nevertheless, we suggest that antibiotics in pregnancy may affect the bacterial ecosystem of the mother as well as that of the 
fetus, and therefore that their use should be carefully considered based on what is known, and what remains unknown, regarding their effects.

Recent studies have demonstrated that priming of the immune system and microbiota-driven immune changes begin in utero and are not - as traditionally believed induced postnatally by the newborn's microbiota [35]. These new insights suggest that the maternal microbiota during pregnancy actually drives early postnatal innate immune development [36]. It is becoming clearer that the maternal microbiota, in concert with maternal antibodies, are important in preparing the fetus for hostmicrobial symbiosis later in life. The mechanisms of this phenomenon are now being explored and involve microbial molecular transfer (without any live bacteria). In addition, maternal antibodies have a dual effect, promoting pathogen neutralization whilst simultaneously enhancing microbial molecular transfer. Gomez de Aguero et al. [36] recently showed that pups of mothers transiently colonized during pregnancy have a greater capacity to avoid inflammation in response to bacterial molecules and penetration of intestinal microbes. Thus, the maternal microbiota plays a role in shaping the postnatal immune system and interferences with maternal microbiota during pregnancy may hinder the natural process of prenatal immune priming.

We believe that the issue of antibiotics during pregnancy is one of the greatest challenges of human microbiome research and certainly deserves increased focus in the form of observational and interventional studies to unravel the role of these drugs in human development.

\section{Summary and future directions}

One may argue for the importance of antibiotics during pregnancy to prevent or treat bacterial infections. Indeed, antibiotics have an important role in improving and promoting health in pregnant women. Nevertheless, as with other therapeutic modalities, overuse may be counterproductive. The realization that antibiotic use in pregnancy may interfere with the delicate balance between the pregnant woman's microbiota, which is important for normal fetal development, may gradually decrease the enormous, and possibly excessive, utilization of these drugs during pregnancy. In case of proven maternal infection, narrow spectrum antibiotics should be preferred due to their less extensive effects on the microbiome, taking into account the association of prenatal antibiotics with increased risk of childhood asthma, epilepsy, and obesity. Future studies should focus on maternal microbiome manipulations such as personalized probiotics and fecal microbiota transplantation, and their effect on pregnancy outcome, as well as on the use of specific microbial profiling for diagnosis of pregnancy complications and prediction of long-term outcomes of newborn and maternal health.

\section{Acknowledgements}

The authors thank Noa llan for preparing the illustrations.

\section{Funding}

The work of OK is supported by the Marie Curie International Reintegration Grant (FP7-PEOPLE-2013-CIG-630956), the Ministry of Health, State of Israel (3-0000-10451), and the Canadian-Israel Health Initiative, jointly funded by the Canadian Institutes of Health Research, the Israel Science Foundation, the International Development Research Centre, Canada, and the Azrieli Foundation.

\section{Authors' contributions}

AAK and OK wrote the manuscript and agreed upon the final version of the paper.

\section{Author information}

AAK is a physician-scientist, head of the Pediatric Hematology and Blood Coagulation Service at the Galilee Medical Center. He is currently performing $\mathrm{PhD}$ research at the Microbiome Research Lab, Bar-llan University. OK is a microbiologist, a principal investigator involved in human microbiome research, and head of the Microbiome Research Lab at Bar-llan University.

\section{Competing interests}

The authors declare that they have no competing interests.

\section{Author details}

${ }^{1}$ Blood Coagulation Service and Pediatric Hematology Clinic, Galilee Medical Center, Nahariya, Israel. ' Faculty of Medicine in the Galilee, Bar-Ilan University, Henrietta Szold St. 8, POB 1589 Safed, Israel.

Received: 5 February 2016 Accepted: 3 June 2016

Published online: 17 June 2016

\section{References}

1. Human Microbiome Project Consortium. Structure, function and diversity of the healthy human microbiome. Nature. 2012;486(7402):207-14.

2. Ley RE. Obesity and the human microbiome. Curr Opin Gastroenterol. 2010; 26(1):5-11.

3. Tilg $H$, Moschen AR. Microbiota and diabetes: an evolving relationship. Gut. 2014;63(9):1513-21.

4. Koren O, Goodrich JK, Cullender TC, Spor A, Laitinen K, Backhed HK, Gonzalez A, Werner JJ, Angenent LT, Knight R, et al. Host remodeling of the gut microbiome and metabolic changes during pregnancy. Cell. 2012; 150(3):470-80.

5. Markle JG, Frank DN, Mortin-Toth S, Robertson CE, Feazel LM, RolleKampczyk U, von Bergen M, McCoy KD, Macpherson AJ, Danska JS. Sex differences in the gut microbiome drive hormone-dependent regulation of autoimmunity. Science. 2013;339(6123):1084-8.

6. Newbern D, Freemark M. Placental hormones and the control of maternal metabolism and fetal growth. Curr Opin Endocrinol Diabetes Obes. 2011; 18(6):409-16.

7. Aagaard K, Riehle K, Ma J, Segata N, Mistretta TA, Coarfa C, Raza S, Rosenbaum S, Van den Veyver I, Milosavljevic A, et al. A metagenomic approach to characterization of the vaginal microbiome signature in pregnancy. PLoS One. 2012;7(6), e36466.

8. Zhang D, Huang Y, Ye D. Intestinal dysbiosis: an emerging cause of pregnancy complications? Med Hypotheses. 2015;84(3):223-6.

9. Chernikova DA, Koestler DC, Hoen AG, Housman ML, Hibberd PL, Moore JH, Morrison HG, Sogin ML, Zain-Ul-Abideen M, Madan JC. Fetal exposures and perinatal influences on the stool microbiota of premature infants. J Matern Fetal Neonatal Med. 2016;29(1):99-105.

10. Branton WG, Ellestad KK, Maingat F, Wheatley BM, Rud E, Warren RL, Holt RA, Surette MG, Power C. Brain microbial populations in HIV/AIDS: alphaproteobacteria predominate independent of host immune status. PLoS One. 2013;8(1), e54673.

11. Potgieter M, Bester J, Kell DB, Pretorius E. The dormant blood microbiome in chronic, inflammatory diseases. FEMS Microbiol Rev. 2015;39(4):567-91.

12. Marsland BJ, Gollwitzer ES. Host-microorganism interactions in lung diseases. Nat Rev Immunol. 2014;14(12):827-35.

13. Nakatsuji T, Chiang HI, Jiang SB, Nagarajan H, Zengler K, Gallo RL. The microbiome extends to subepidermal compartments of normal skin. Nat Commun. 2013;4:1431. 
14. Aagaard K, Ma J, Antony KM, Ganu R, Petrosino J, Versalovic J. The placenta harbors a unique microbiome. Sci Transl Med. 2014;6(237):237ra265.

15. Tissier $H$. Recherches sur la flore intestinale des nourrissons (e'tat normal et pathologique). Paris: G. Carre and C. Naud. 1900.

16. Kovalovszki L, Villanyi Z, Pataki I, Veszelowvsky I, Nagy ZB. Isolation of aerobic bacteria from the placenta. Acta Paediatr Acad Sci Hung. 1982;23(3): 357-60

17. Goldenberg RL, Culhane JF, lams JD, Romero R. Epidemiology and causes of preterm birth. Lancet. 2008;371(9606):75-84.

18. Goepfert AR, Jeffcoat MK, Andrews WW, Faye-Petersen O, Cliver SP, Goldenberg RL, Hauth JC. Periodontal disease and upper genital tract inflammation in early spontaneous preterm birth. Obstet Gynecol. 2004; 104(4):777-83.

19. Galask RP, Varner MW, Petzold CR, Wilbur SL. Bacterial attachment to the chorioamniotic membranes. Am J Obstet Gynecol. 1984;148(7):915-28.

20. Doyle RM, Alber DG, Jones HE, Harris K, Fitzgerald F, Peebles D, Klein N. Term and preterm labour are associated with distinct microbial community structures in placental membranes which are independent of mode of delivery. Placenta. 2014;35(12):1099-101.

21. Kliman HJ. Comment on "the placenta harbors a unique microbiome". Sci Transl Med. 2014;6(254):254le254.

22. Bookstaver PB, Bland CM, Griffin B, Stover KR, Eiland LS, McLaughlin M. A review of antibiotic use in pregnancy. Pharmacotherapy. 2015;35(11):1052-62.

23. Tormo-Badia N, Hakansson A, Vasudevan K, Molin G, Ahrne S, Cilio CM. Antibiotic treatment of pregnant non-obese diabetic mice leads to altered gut microbiota and intestinal immunological changes in the offspring. Scand J Immunol. 2014;80(4):250-60.

24. Stokholm J, Schjorring S, Eskildsen CE, Pedersen L, Bischoff AL, Folsgaard N, Carson CG, Chawes BL, Bonnelykke K, Molgaard A, et al. Antibiotic use during pregnancy alters the commensal vaginal microbiota. Clin Microbiol Infect. 2014;20(7):629-35.

25. Mueller NT, Whyatt R, Hoepner L, Oberfield S, Dominguez-Bello MG, Widen EM, Hassoun A, Perera F, Rundle A. Prenatal exposure to antibiotics, cesarean section and risk of childhood obesity. Int J Obesity. 2015:39(4):665-70.

26. Roberts DJ, Celi AC, Riley LE, Onderdonk AB, Boyd TK, Johnson LC, Lieberman E. Acute histologic chorioamnionitis at term: nearly always noninfectious. PLoS One. 2012;7(3), e31819.

27. Kenyon SL, Taylor DJ, Tarnow-Mordi W, ORACLE Collaborative Group. Broadspectrum antibiotics for preterm, prelabour rupture of fetal membranes: the ORACLE I randomised trial. ORACLE Collaborative Group. Lancet. 2001; 357(9261):979-88

28. Kenyon S, Pike K, Jones DR, Brocklehurst P, Marlow N, Salt A, Taylor DJ. Childhood outcomes after prescription of antibiotics to pregnant women with spontaneous preterm labour: 7-year follow-up of the ORACLE II trial. Lancet. 2008;372(9646):1319-27.

29. Ledger WJ, Blaser MJ. Are we using too many antibiotics during pregnancy? BJOG. 2013:120(12):1450-2.

30. Flenady V, Hawley G, Stock OM, Kenyon S, Badawi N. Prophylactic antibiotics for inhibiting preterm labour with intact membranes. Cochrane Database Syst Rev. 2013;12, CD000246.

31. De La Cochetiere MF, Durand T, Lepage P, Bourreille A, Galmiche JP, Dore J. Resilience of the dominant human fecal microbiota upon short-course antibiotic challenge. J Clin Microbiol. 2005:43(11):5588-92.

32. Lapin B, Piorkowski J, Ownby D, Freels S, Chavez N, Hernandez E, Wagner-Cassanova C, Pelzel D, Vergara C, Persky V. Relationship between prenatal antibiotic use and asthma in at-risk children. Ann Allergy Asthma Immunol. 2015;114(3):203-7.

33. Metsala J, Lundqvist A, Virta LJ, Kaila M, Gissler M, Virtanen SM. Prenatal and post-natal exposure to antibiotics and risk of asthma in childhood. Clin Exp Allergy. 2015;45(1):137-45.

34. Stensballe LG, Simonsen J, Jensen SM, Bonnelykke K, Bisgaard H. Use of antibiotics during pregnancy increases the risk of asthma in early childhood. J Pediatr. 2013;162(4):832-8. e3

35. Rakoff-Nahoum S, Kong Y, Kleinstein SH, Subramanian S, Ahern PP, Gordon الر Medzhitov R. Analysis of gene-environment interactions in postnatal development of the mammalian intestine. Proc Natl Acad Sci U S A. 2015; 112(7):1929-36.

36. Gomez de Aguero M, Ganal-Vonarburg SC, Fuhrer T, Rupp S, Uchimura Y, Li H, Steinert A, Heikenwalder M, Hapfelmeier S, Sauer U, et al. The maternal microbiota drives early postnatal innate immune development. Science. 2016; 351(6279):1296-302.
37. Bearfield C, Davenport ES, Sivapathasundaram V, Allaker RP. Possible association between amniotic fluid micro-organism infection and microflora in the mouth. BJOG. 2002;109(5):527-33.

38. Cahill RJ, Tan S, Dougan G, O'Gaora P, Pickard D, Kennea N, Sullivan MH, Feldman RG, Edwards AD. Universal DNA primers amplify bacterial DNA from human fetal membranes and link Fusobacterium nucleatum with prolonged preterm membrane rupture. Mol Hum Reprod. 2005;11(10):761-6.

39. Kim MJ, Romero R, Gervasi MT, Kim JS, Yoo W, Lee DC, Mittal P, Erez O, Kusanovic JP, Hassan SS, et al. Widespread microbial invasion of the chorioamniotic membranes is a consequence and not a cause of intraamniotic infection. Lab Invest. 2009;89(8):924-36.

40. Stout MJ, Conlon B, Landeau M, Lee I, Bower C, Zhao Q, Roehl KA, Nelson DM, Macones GA, Mysorekar IU. Identification of intracellular bacteria in the basal plate of the human placenta in term and preterm gestations. Am J Obstet Gynecol. 2013;208(3):e1-7.

41. Barak S, Oettinger-Barak O, Machtei EE, Sprecher H, Ohel G. Evidence of periopathogenic microorganisms in placentas of women with preeclampsia. J Periodontol. 2007;78(4):670-6.

42. Bhola K, Al-Kindi H, Fadia M, Kent AL, Collignon P, Dahlstrom JE. Placental cultures in the era of peripartum antibiotic use. Aust N Z J Obstet Gynaecol. 2008:48(2):179-84

43. Daoud GA, Suzuki Y, Yamamoto T, Suzuki T, Suzumori N, Tanemura M. Establishment of a polymerase chain reaction method for detection of Escherichia coli in amniotic fluid in patients with chorioamnionitis. Fetal Diagn Ther. 2008;24(2):132-9.

44. Gomez R, Romero R, Nien JK, Medina L, Carstens M, Kim YM, Espinoza J, Chaiworapongsa T, Gonzalez R, lams JD, et al. Antibiotic administration to patients with preterm premature rupture of membranes does not eradicate intra-amniotic infection. J Matern Fetal Neonatal Med. 2007;20(2):167-73.

45. Nguyen DP, Gerber S, Hohlfeld P, Sandrine G, Witkin SS. Mycoplasma hominis in mid-trimester amniotic fluid: relation to pregnancy outcome. J Perinat Med. 2004;32(4):323-6.

46. Onderdonk AB, Hecht JL, McElrath TF, Delaney ML, Allred EN, Leviton A, Investigators ES. Colonization of second-trimester placenta parenchyma. Am J Obstet Gynecol. 2008;199(1):52. e1-52.

47. Pankuch GA, Appelbaum PC, Lorenz RP, Botti JJ, Schachter J, Naeye RL. Placental microbiology and histology and the pathogenesis of chorioamnionitis. Obstet Gynecol. 1984;64(6):802-6.

48. Patrascu A, Berceanu S, Popescu CF, Gheorman V, Berceanu C. Clinical and histopathological correlations of the modifications of fetal membranes in amniochorial infection. Rom J Morphol Embryol. 2009;50(1):67-72.

49. Queiros da Mota V, Prodhom G, Yan P, Hohlfheld P, Greub G, Rouleau C. Correlation between placental bacterial culture results and histological chorioamnionitis: a prospective study on 376 placentas. J Clin Pathol. 2013; 66(3):243-8.

50. Romero R, Miranda J, Chaiworapongsa T, Chaemsaithong P, Gotsch F, Dong Z, Ahmed Al, Yoon BH, Hassan SS, Kim CJ,et al. A novel molecular microbiologic technique for the rapid diagnosis of microbial invasion of the amniotic cavity and intra-amniotic infection in preterm labor with intact membranes. Am J Reprod Immunol. 2014;71(4):330-58.

51. Amarasekara R, Jayasekara RW, Senanayake H, Dissanayake VH. Microbiome of the placenta in pre-eclampsia supports the role of bacteria in the multifactorial cause of pre-eclampsia. J Obstet Gynaecol Res. 2015:41(5):662-9.

52. Antony KM, Ma J, Mitchell KB, Racusin DA, Versalovic J, Aagaard K. The preterm placental microbiome varies in association with excess maternal gestational weight gain. Am J Obstet Gynecol. 2015;212(5):653. e1-16.

53. Blanchard A, Hamrick W, Duffy L, Baldus K, Cassell GH. Use of the polymerase chain reaction for detection of Mycoplasma fermentans and Mycoplasma genitalium in the urogenital tract and amniotic fluid. Clin Infect Dis. 1993;17 Suppl 1:S272-9.

54. Clark P, Trickett A, Stark D, Vowels M. Factors affecting microbial contamination rate of cord blood collected for transplantation. Transfusion. 2012;52(8):1770-7.

55. Gerber S, Vial Y, Hohlfeld P, Witkin SS. Detection of Ureaplasma urealyticum in second-trimester amniotic fluid by polymerase chain reaction correlates with subsequent preterm labor and delivery. J Infect Dis. 2003;187(3):518-21.

56. Harvey BS, Koeuth T, Versalovic J, Woods CR, Lupski JR. Vertical transmission of Citrobacter diversus documented by DNA fingerprinting. Infect Control Hosp Epidemiol. 1995;16(10):564-9.

57. Hitti J, Riley DE, Krohn MA, Hillier SL, Agnew KJ, Krieger JN, Eschenbach DA. Broad-spectrum bacterial rDNA polymerase chain reaction assay for 
detecting amniotic fluid infection among women in premature labor. Clin Infect Dis. 1997;24(6):1228-32.

58. Jalava J, Mantymaa ML, Ekblad U, Toivanen P, Skurnik M, Lassila O, Alanen A. Bacterial 165 rDNA polymerase chain reaction in the detection of intraamniotic infection. Br J Obstet Gynaecol. 1996;103(7):664-9.

59. Markenson GR, Adams LA, Hoffman DE, Reece MT. Prevalence of Mycoplasma bacteria in amniotic fluid at the time of genetic amniocentesis using the polymerase chain reaction. J Reprod Med. 2003;48(10):775-9.

60. Mostajeran F, Arbabi B. Is there any difference between preeclamptic and healthy pregnant women regarding the presence of periopathogenic bacteria in the placenta? Int J Prev Med. 2013:4(3):322-6.

61. Satokari R, Gronroos T, Laitinen K, Salminen S, Isolauri E. Bifidobacterium and Lactobacillus DNA in the human placenta. Lett Appl Microbiol. 2009;48(1):8-12.

62. Watt S, Lanotte P, Mereghetti L, Moulin-Schouleur M, Picard B, Quentin R. Escherichia coli strains from pregnant women and neonates: intraspecies genetic distribution and prevalence of virulence factors. J Clin Microbiol. 2003;41(5):1929-35.

63. Gomez R, Romero R, Nien JK, Medina L, Carstens M, Kim YM, Chaiworapongsa T, Espinoza J, Gonzalez R. Idiopathic vaginal bleeding during pregnancy as the only clinical manifestation of intrauterine infection. J Matern Fetal Neonatal Med. 2005;18(1):31-7.

64. Han YW, Ikegami A, Bissada NF, Herbst M, Redline RW, Ashmead GG Transmission of an uncultivated Bergeyella strain from the oral cavity to amniotic fluid in a case of preterm birth. J Clin Microbiol. 2006;44(4):1475-83.

65. Hassan S, Romero R, Hendler I, Gomez R, Khalek N, Espinoza J, Nien JK, Berry SM, Bujold E, Camacho N, et al. A sonographic short cenvix as the only clinical manifestation of intra-amniotic infection. J Perinat Med. 2006;34(1):13-9.

66. Kim KW, Romero R, Park HS, Park CW, Shim SS, Jun JK, Yoon BH. A rapid matrix metalloproteinase-8 bedside test for the detection of intraamniotic inflammation in women with preterm premature rupture of membranes. Am J Obstet Gynecol. 2007;197(3):292. e1-5.

67. Kirchner L, Helmer H, Heinze G, Wald M, Brunbauer M, Weninger M, Zaknun D. Amnionitis with Ureaplasma urealyticum or other microbes leads to increased morbidity and prolonged hospitalization in very low birth weight infants. Eur J Obstet Gynecol Reprod Biol. 2007;134(1):44-50.

68. Musilova I, Pliskova L, Kutova R, Jacobsson B, Paterova P, Kacerovsky M. Streptococcus agalactiae in pregnancies complicated by preterm prelabor rupture of membranes. J Matern Fetal Neonatal Med. 2016;29(7):1036-40.

69. Yoon BH, Romero R, Park JS, Kim M, Oh SY, Kim CJ, Jun JK. The relationship among inflammatory lesions of the umbilical cord (funisitis), umbilical cord plasma interleukin 6 concentration, amniotic fluid infection, and neonatal sepsis. Am J Obstet Gynecol. 2000;183(5):1124-9.

70. Han YW, Shen T, Chung P, Buhimschi IA, Buhimschi CS. Uncultivated bacteria as etiologic agents of intra-amniotic inflammation leading to preterm birth. J Clin Microbiol. 2009:47(1):38-47.

71. DiGiulio DB, Gervasi MT, Romero R, Vaisbuch E, Mazaki-Tovi S, Kusanovic JP, Seok KS, Gomez R, Mittal P, Gotsch F, et al. Microbial invasion of the amniotic cavity in pregnancies with small-for-gestational-age fetuses. J Perinat Med. 2010;38(5):495-502.

72. DiGiulio DB, Gervasi M, Romero R, Mazaki-Tovi S, Vaisbuch E, Kusanovic JP, Seok KS, Gomez R, Mittal P, Gotsch F, et al. Microbial invasion of the amniotic cavity in preeclampsia as assessed by cultivation and sequencebased methods. J Perinat Med. 2010;38(5):503-13.

73. Onderdonk AB, Delaney ML, DuBois AM, Allred EN, Leviton A. Extremely Low Gestational Age Newborns (ELGAN) Study Investigators. Detection of bacteria in placental tissues obtained from extremely low gestational age neonates. Am J Obstet Gynecol. 2008;198(1):110. e1-7.

\section{Submit your next manuscript to BioMed Central and we will help you at every step:}

- We accept pre-submission inquiries

- Our selector tool helps you to find the most relevant journal

- We provide round the clock customer support

- Convenient online submission

- Thorough peer review

- Inclusion in PubMed and all major indexing services

- Maximum visibility for your research

Submit your manuscript at www.biomedcentral.com/submit
() BioMed Central 